GMR

\title{
Genetic divergence among Psidium accessions based on single nucleotide polymorphisms developed for Eucalyptus
}

\author{
S.R. Costa $^{1}$ and C.A.F. Santos ${ }^{2}$ \\ ${ }^{1}$ Programa de Pós-graduação em Recursos Genéticos Vegetais, \\ Universidade Estadual de Feira de Santana, Feira de Santana, BA, Brasil \\ ${ }^{2}$ Embrapa Semiárido, Petrolina, PE, Brasil \\ Corresponding author: S.R. Costa \\ E-mail: anne tecnologa@hotmail.com \\ Genet. Mol. Res. 16 (2): gmr16029566 \\ Received December 7, 2016 \\ Accepted April 19, 2017 \\ Published May 4, 2017 \\ DOI http://dx.doi.org/10.4238/gmr16029566 \\ Copyright (C) 2017 The Authors. This is an open-access article distributed under the terms of \\ the Creative Commons Attribution ShareAlike (CC BY-SA) 4.0 License.
}

\begin{abstract}
The goal of this study was to analyze the genetic divergence among Psidium species accessions based on SNPs developed for Eucalyptus. Fifty-three Psidium accessions, including 47 P. guajava, were genotyped with EUCHIP60K. The dendrogram similarity ranged from 0.58 to 1.00 , with a cophenetic value of 0.97 . Five groups were identified at dendrogram cut point of 0.7 : the first with 44 guava accessions, the second with 1 guava accession, the third with 3 P. guineense accessions, the forth with 2 guava accessions, and the fifth with 3 P. cattleianum accessions. The Bayesian analyses suggested seven subpopulations, with formation of two additional groups with guava accessions. Primers designed with Eucalyptus SNP sequences resulted in reliable Psidium amplicons on $6 \%$ polyacrylamide gels. In general, the SNP dendrogram agreed with biological genus structure, since different species were not grouped, indicating that transferability among Myrtaceae genus was possible and reliable.
\end{abstract}

Key words: SNP; Transferability; Dendrogram

Genetics and Molecular Research 16 (2): gmr16029566 


\section{INTRODUCTION}

The Myrtaceae family consists of approximately 130 genera and 3000 species of trees and shrubs distributed mainly throughout the tropics and subtropics. Brazil is a great representative of this diversity, where a total of 60 species can be found, including 47 endemic species (Sobral et al., 2016). Guava species is one of the highest economic values in Psidium. It is an important fruit in Brazil and in the world, and can be consumed both in natura and in its industrialized form. The fruit has good content of vitamin C (ascorbic acid), citrus juices being good sources (Pommer et al., 2013).

The root-knot nematode Meloidogyne enterolobii is currently responsible for the declining production of guava in Brazil. For presenting important sources of alleles, wild species of Psidium have been introduced in guava improvement program as a source of resistance to the nematode $M$. enterolobii, as reported by Costa et al. (2012), with the development of $P$. guajava x $P$. guineense hybrid. Several studies regarding characterization of guava and / or wild Psidium were carried out by using molecular markers.

Hernández-Delgado et al. (2007) analyzed 52 Psidium accessions from a Mexican collection based on AFLP markers. These authors observed the formation of two main groups, the first consisting of $P$. cattleianum and $P$. friedrichsthalianum accessions, and the second by $P$. guajava accessions. Rueda et al. (2006) characterized 27 guava accessions of Psidium ssp from a Colombian Research Center collection based on RAPD markers, reporting the formation of 16 groups, with a 0.78 similarity index. Pessanha et al. (2011) evaluated the genetic similarity of 20 Psidium ssp accessions using RAPD markers and the dendrogram generated two groups: the first containing guava species and the second containing $P$. guineense accessions. ValdésInfante et al. (2007) reported the characterization of guava accessions of Cuban origin with microsatellites. da Costa and Santos (2013), in a study of four Psidium species, comprising 61 accessions, reported similarity between $P$. guajava and $P$. guineense of $82.4 \%$ through SSR markers. Kidaha et al. (2014) characterized 58 guava cultivars in Kenya through SSR and ISSR markers. To our knowledge there are no genetic divergence studies based on single nucleotide polymorphisms (SNPs) in Psidium and no reported attempts to transfer SNPs from one species to another, in general.

The goal of this study was to analyze the genetic divergence among $P$. guajava and Psidium sp accessions based on SNPs developed for Eucalyptus species in order to orientate guava genetic resources and breeding programs.

\section{MATERIAL AND METHODS}

\section{Plant materials}

Fifty-three Psidium accessions were analyzed, including 47 accessions of $P$. guajava, 3 P. guineense accessions, and 3 P. cattleianum accessions belonging to the germplasm bank of guava and wild Psidium of Embrapa Semiarid, located in the experimental field of Bebedouro, Petrolina, PE (Table 1).

\section{Extraction and quantification of DNA}

New and healthy leaves of 53 Psidium accessions were collected in paper bags, duly

Genetics and Molecular Research 16 (2): gmr16029566 
identified, and conditioned in a freezer at $-80^{\circ} \mathrm{C}$ until DNA extraction. DNA was extracted according to the method proposed by Doyle and Doyle (1990) with modifications as described by da Costa and Santos (2013). The DNA was quantified on $0.8 \%$ agarose gel stained with ethidium bromide by visually comparing the intensity of the DNA bands extracted with those of bands of Lambda phage DNA. The samples were diluted to $10 \mathrm{ng} / \mu \mathrm{L}$ and stocked at $-20^{\circ} \mathrm{C}$.

Table 1. Origin of guava and wild Psidium accessions from the Embrapa Semiarid germplasm collection.

\begin{tabular}{|c|c|c|c|c|c|}
\hline Acession & Origin & State & Accession & Origin & State \\
\hline GUA87AM & Iranduba & $\mathrm{AM}$ & GUA68RO & Buritis & $\mathrm{RO}$ \\
\hline GUA88AM & Iranduba & $\mathrm{AM}$ & GUA72RO & Monte Negro & RO \\
\hline GUA90AM & Iranduba & $\mathrm{AM}$ & GUA73RO & Ariquemes & RO \\
\hline GUA92AM & Manacapuru & $\mathrm{AM}$ & GUA81RO & Porto Velho & RO \\
\hline GUA97AM & Autazes & $\mathrm{AM}$ & GUA82RO & Porto Velho & RO \\
\hline GUA98AM & Autazes & $\mathrm{AM}$ & GUA133RR & Iracema & RR \\
\hline GUA62BA & Antonio Gonçalves & BA & GUA 135RR & Iracema & RR \\
\hline GUA146BA & Valença & BA & GUA136RR & Rorainópolis & RR \\
\hline GUA147BA & Valença & BA & GUA137RR & Caracarái & $\mathrm{RR}$ \\
\hline GUA150BA & Nilo Peçanha & BA & GUA138RR & Boa Vista & RR \\
\hline ARA153BA & Ituberá & $\mathrm{BA}$ & ARA138RR & Boa Vista & RR \\
\hline GUA117GO & Morrinhos & GO & ARA140RR & Boa Vista & RR \\
\hline GUA120GO & Goiás Velho & $\mathrm{GO}$ & ARA55RS & Pelotas & RS \\
\hline GUA121GO & Goiás Velho & GO & ARA58RS & Pelotas & RS \\
\hline GUA124GO & Santa Isabel & GO & ARA105RS & Pelotas & RS \\
\hline GUA127GO & Mimoso de Goiás & GO & GUA104RS & Pelotas & RS \\
\hline GUA02MA & Caxias & MA & GUA106RS & Pelotas & $\mathrm{RS}$ \\
\hline GUA03MA & Coelho Neto & MA & GUA109RS & Pelotas & RS \\
\hline GUA05MA & Buriti & MA & GUA110RS & Pelotas & RS \\
\hline GUA07MA & Mata Roma & MA & GUA51SE & Capela & SE \\
\hline GUA26MA & Paraibano & MA & GUA52SE & Capela & SE \\
\hline GUA33PE & Ibimirim & PE & GUA53SE & Japoratuba & SE \\
\hline GUA34PE & Ibimirim & $\mathrm{PE}$ & GUA55SE & Pirambu & SE \\
\hline GUA36PE & Pesqueira & $\mathrm{PE}$ & GUA59SE & Umbamba & SE \\
\hline GUA38PE & Pesqueira & $\mathrm{PE}$ & GUA61SE & Riachão dos Dantas & SE \\
\hline GUA39PE & Belo Jardim & PE & PEDRO SATO & Commercial cultivar & PE \\
\hline GUA67RO & Jaru & RO & & & \\
\hline
\end{tabular}

GUA = Psidium guajava (guava); ARA = Psidium spp (wild Psidium).

\section{Annotation and analysis of SNP data}

DNA samples of accessions were genotyped with 60,904 SNPs of the EUChip60K chip, developed by Silva-Junior et al. (2015). The genotyping services were performed by GeneSeek (Lincoln, NE, USA). SNPs were also amplified in an F2 population of 189 individuals from a cross between $P$. guajava $\mathrm{x} P$. guineense in order to select those with amplifications in both Psidium sets for divergence analysis.

The data generated by SNPs were transformed into binary codes for presence (1) or absence (0) of alleles, to build a matrix of Jaccard similarity index. The dendrogram with distances of accessions was made by the UPGMA grouping method (grouping method not based on weighted average arithmetic). The evaluation of the dendrogram adjustment was performed by cophenetic correlation, or the correlation between the true distances and the graphically represented ones. For these analyses, the NTSYSpc computer application was used (Rophlf, 2000).

Grouping based on model implemented in the Structure software was also used (Pritchard et al., 2000). The Bayesian algorithm in this software identifies genetically distinct subpopulations based on allele frequencies. The analysis to set the number of $\mathrm{K}$ or existing

Genetics and Molecular Research 16 (2): gmr16029566 
subpopulations consisted of four independent replicates, with cutoff values of 100,000 permutations (burning) and 100,000 simulations of Monte Carlo chains.

\section{PCRs and resolution on polyacrylamide gels of Eucalyptus SNPs in Psidium samples}

Primer pairs of selected Eucalyptus SNPs were designed in the public software Primer3 public software (http://bioinfo.ut.ee/primer3/) to amplify Psidium genome regions, including eight samples of $P$. guajava, $P$. guineense, $P$. cattleyanum, and $P$. friedrichsthalianum and eight F2 samples of a $P$. guajava $\mathrm{x} P$. guineense cross.

The PCR amplification was carried out for a final volume of $10 \mu \mathrm{L}$, containing 30 ng DNA, $0.2 \mu \mathrm{L}$ of each primer, 1X Taq DNA polymerase buffer, $2.5 \mathrm{mM} \mathrm{MgCl}, 0.8 \mathrm{mM}$ dNTPs, and $0.75 \mathrm{U}$ of the enzyme Taq DNA polymerase. The amplification program consisted of denaturation of the initial cycle at $94^{\circ} \mathrm{C}$ for $4 \mathrm{~min} ; 37$ cycles at $94^{\circ} \mathrm{C}$ for $45 \mathrm{~s}, 54^{\circ} \mathrm{C}$ for $60 \mathrm{~s}$, and $72^{\circ} \mathrm{C}$ for $60 \mathrm{~s}$; and one stage of final extension at $72^{\circ} \mathrm{C}$ for $5 \mathrm{~min}$. Amplified PCR products were separated on $6 \%$ polyacrylamide gels as described by da Costa and Santos (2013).

\section{RESULTS AND DISCUSSION}

In the experiment, 3523 SNPs of Eucalyptus for Psidium were generated, and 888 SNPs of these were selected for the present diversity analysis, because they also amplified in the F2 population of an interspecific hybrid. The chip EUChip60K is composed of 60,904 SNPs, of which 51,204 were polymorphic in 14 species of Eucalyptus (Silva-Junior et al., 2015). Thus, the amplification of Eucaliptus SNPs to Psidium was nearly $7 \%$, and the effective transferability, by validation criteria in another Psidium sample, almost $2 \%$.

Primers designed based on the EuBR03s4249801, EuBR08s41303533, EuBR03s13633658, EuBR11s17302993, EuBR02s23677860, EuBR03s47452480, EuBR06s21493635, and EuBR10s9300572 Eucalyptus SNPs presented reliable amplifications in Psidium genome (Figure 1), attesting the effective SNP transferability and the presence of conserved genome regions among Myrtaceae species.
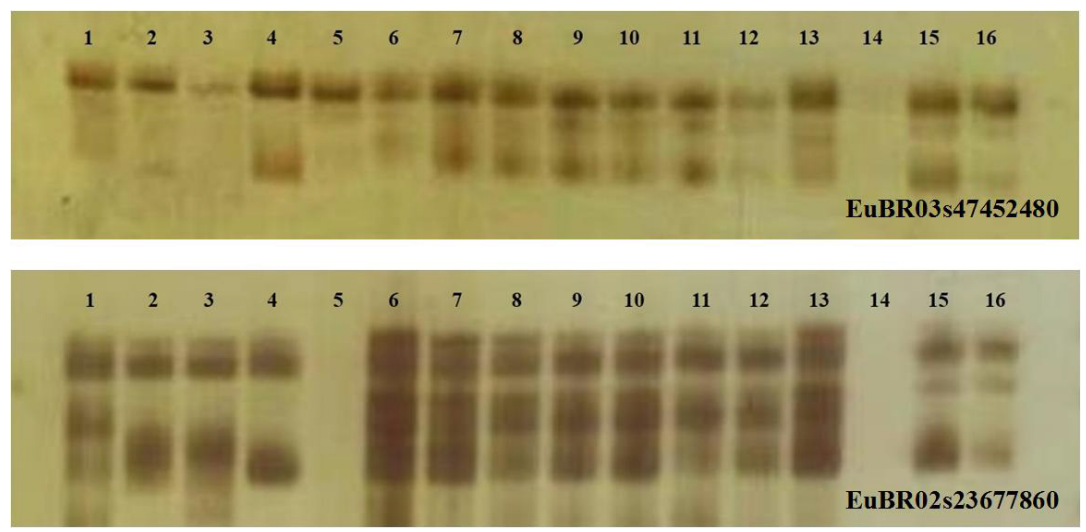

Figure 1. Profile of the PCR products of eight Psidium accessions: Psidium guajava allele (lanes 14, 15, 16); $P$. guineense allele (lanes 1 and 5); P. cattleianum allele (lanes 2 and 3); P. friedrichsthalianum allele (lane 4), and eight F2 plants (lanes 6-13) of a Psidium hybrid allele. Amplicons were amplified by Eucalyptus primers and resolved on silver- stained polyacrylamide gel.

Genetics and Molecular Research 16 (2): gmr16029566 
The genus Psidium and Eucalyptus belong to the same Myrtacea family and transferability of markers between species of the same family has been applied in many studies, including among Myrtaceae species (Rai et al., 2013). In their study, with SSRs markers, these authors reported transferability rate of almost $80 \%$. SNP markers have not been developed to Psidium yet and have been widely used in genetic analysis, due to the limitations of microsatellites and AFLP markers.

\section{Similarity genetic based on dendrogram of Jaccard coefficient}

Based on the numerical matrix, it was possible to obtain the distance matrix between individuals with use of the Jaccad Index. The correlation between the matrix of cophenetic values and the similarity distance matrix was 0.97 , indicating that the dendrogram (Figure 2) presented a great adjustment in groups of Psidium accessions.

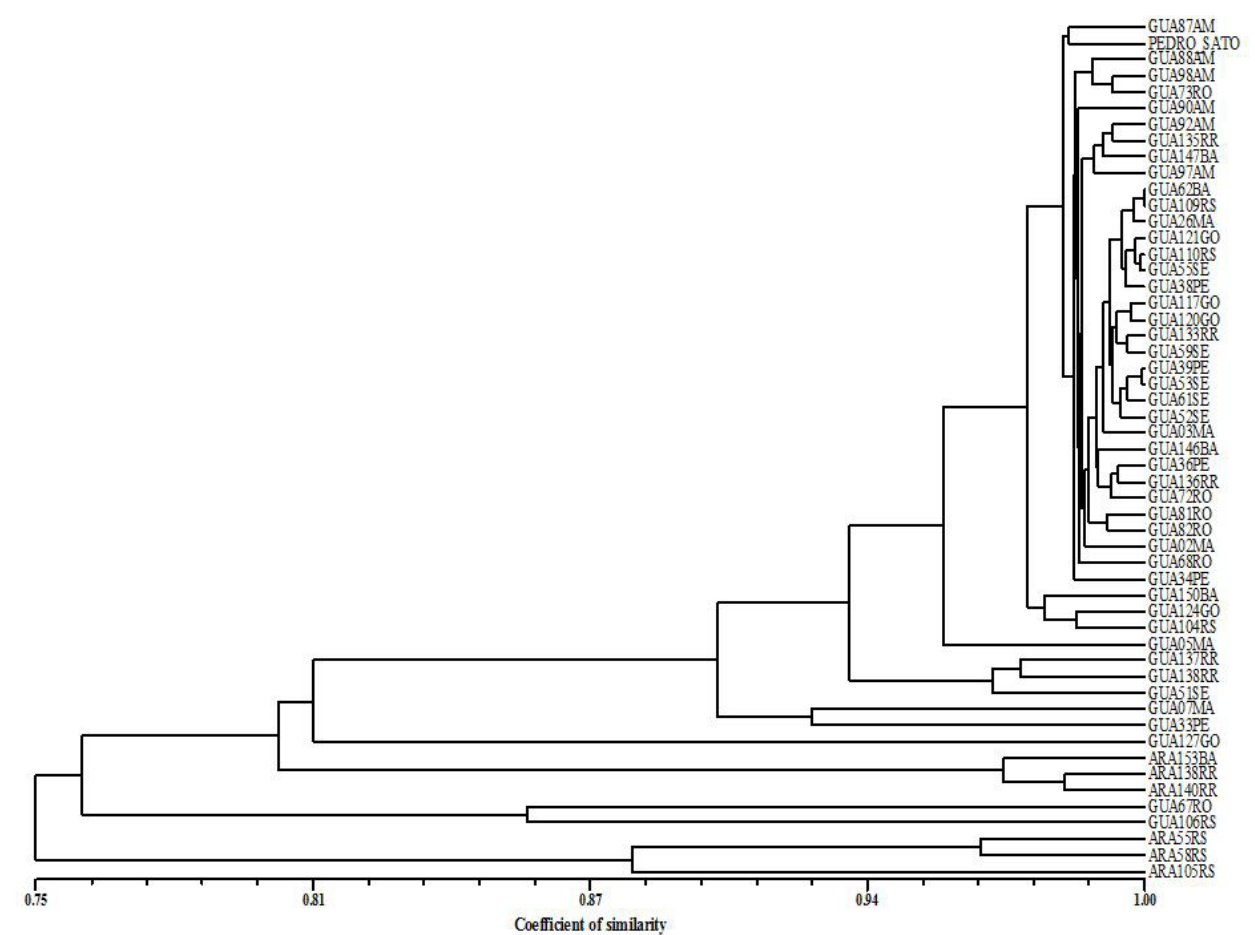

Figure 2. UPGMA dendrogram of Jaccard coefficient among 53 Psidium accessions of the Embrapa Semiarid germplasm collection based on 888 SNPs of Eucalyptus. Cophenetic correlation coefficient $=0.97$.

The similarity among accessions ranged from 0.58 to 1.00 reflecting the existence of high genetic variability among studied accessions. High genetic variability was also reported by da Costa and Santos (2013) among the 61 Psidium accessions of that same collection evaluated by microsatellite marker. Corrêa et al. (2011) also reported high genetic variability among 88 Psidium accessions, with similarities ranging from 0.28 to 0.98 based on AFLP markers. These results indicate high discriminative power of SNP markers, even among

Genetics and Molecular Research 16 (2): gmr16029566 
genetically related materials when compared to results obtained with AFLP and SSR markers for the same collection of accessions.

The 888 SNPs were efficient for separating the 53 Psidium accessions, indicating the formation of five groups at the cutoff point of 0.70 (Figure 2): group I was formed exclusively by guava accessions, from accession GUA87AM to GUA33PE; group II was formed by accession GUA127; group III was formed by the three accessions of $P$. guineense; group IV was formed by guava accessions GUA67 RO and GUA106 RS; and the group V was formed by the three accessions of $P$. cattleianum. The largest number of accessions were clustered in group I, comprising 44 of the 53 accessions, formed exclusively by guava accessions. The same grouping pattern was observed by da Costa and Santos (2013) based on microsatellite markers and Briceño et al. (2010) among Venezuelan accessions of guava and other species of Psidium such as $P$. guineense. The highest similarity (100\%) was observed among the accessions GUA62BA and GUA109RS collected in different regions, Antonio Gonçalves, BA, and Pelotas, RS, respectively. This result was not observed in the study by da Costa and Santos (2013).

The accessions ARA55RS, ARA58RS, and ARA105RS present the least similarity in relation to the set of evaluated accesses. da Costa and Santos (2013) analyzed the genetic variability of these accessions by microsatellite markers and observed that these wild Psidium accessions also showed less similarity in relation to other accessions, confirming the results obtained with SNPs.

It was observed that the six wild Psidium accessions, ARA153BA, ARA138 RR, ARA140 RR (P. guineense), ARA55RS, ARA58RS, and ARA105RS (P. cattleianum), and two guava accessions, GUA67RO and GUA106RS, were positioned at the base of the dendrogram, suggesting greater similarity between accessions. These results are promising since the resistance of plants of the species $P$. guineense and $P$. cattleianum to the nematode was found (Almeida et al., 2009; Miranda et al., 2011; Castro et al., 2012) being indicated for interspecific crosses.

Sitther et al. (2014) reported the formation of six groups composed of eight accessions of $P$. guajava, including three species of wild Psidium accessions of $P$. friedrichsthalianum, $P$. guineense, and P. sartorianum in the United States germplasm. Oliveira et al. (2014) found greater proximity of $P$. cattleianum with guava accessions. However, these species possess proven differences concerning evolutionary distance in relation to guava, mainly because it is polyploid, being evidenced different ploidy levels, such as tetraploid, heptaploide, or octaploide (Costa et al., 2008; Ray, 2002; Singh and Sehgal, 1980; Hirano, 1967). Overall, the reported results and those obtained in this study indicate a clear separation of Psidium species, attesting the efficiency of Eucalyptus SNPs transfer to Psidium.

\section{Genetic structure based on Bayesian analysis}

The number of subpopulations suggested in the analyses of the Structure and Structure Harvester software was seven $(K=7)$ (Figures 3 and 4$)$. The results based on Bayesian analysis were similar to those found by UPGMA (Figure 2), with the identification of the three main groups, separating the three Psidium species evaluated. There were minor discrepancies such as formation of two unique groups to GUA67R and GUA106RS in Bayesian analysis (Figure 3). UPGMA grouping number would be the same in the Bayesian analysis if the cutoff point in the dendrogram had been around 0.80 .

Genetics and Molecular Research 16 (2): gmr16029566 


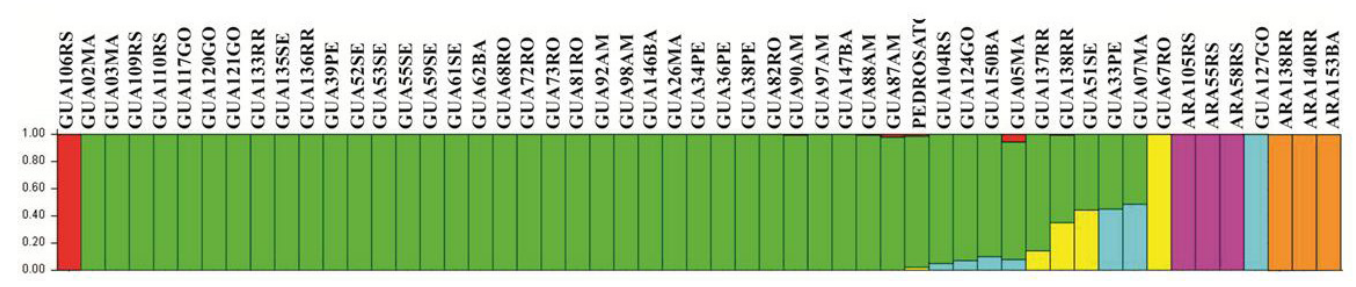

Figure 3. Genetic structure of 53 Psidium accessions generated based on Bayesian analysis, considering $\mathrm{K}=7$, obtained by the method $\Delta \mathrm{K}$. Each vertical line represents a Psidium accession. Each color represents the most probable lineage of the set from which the genotype or partial genotype was derived.

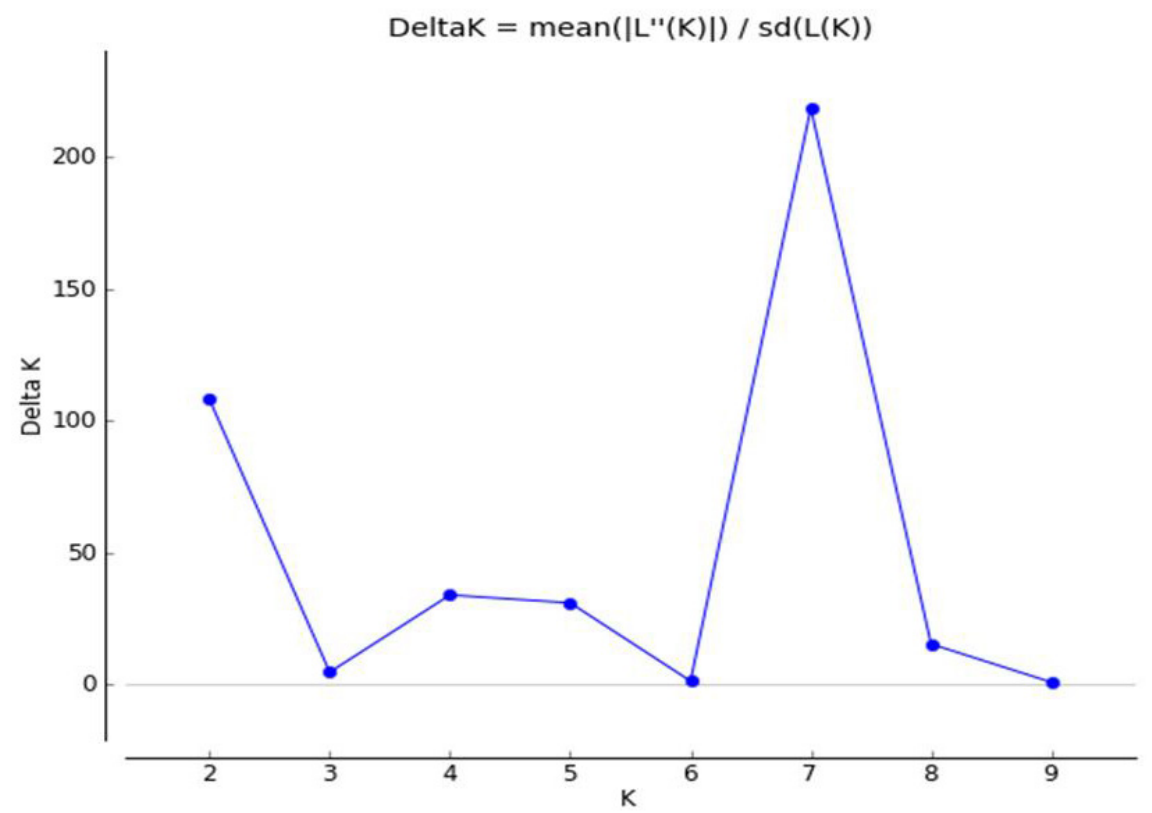

Figure 4. Delta K (filled circles, solid line), calculated with the average rate of second order of change of probability of K divided by the standard deviation probability of K m (| L00 (k) |) / s [L (R)].

When analyzing the information about UPGMA grouping along with Bayesian analysis, it was possible to observe that the guava accession GUA127GO is the one that proves to be more divergent, because it is found isolated from the other accessions. It was observed that the groups formed by wild Psidium accessions formed by Bayesian and UPGMA grouping remained in different groups, both species $P$. cattleianum and $P$. guineense.

da Costa and Santos (2013) while analyzing the genetic diversity of Psidium in that same collection based on microsatellite markers reported the formation of five groups, with a large group of guava accessions and three groups formed only by wild Psidium accessions, one formed by $P$. guineense, other with $P$. cattleianum, and another one containing only P. friedrichsthalianum. These results corroborate with the data presented in this study, demonstrating the efficiency of Eucaliptus SNPs applied in Psidium. 
According to Arriel et al. (2006), studies involving more than one grouping method, due to differences in the hierarchy, optimization and ordering of groups, allow the classification to be complemented by the criterion that each technique uses, as well as prevent erroneous inferences from being adopted in the allocation of materials within a particular subgroup of genotypes.

This is the first study with the application of SNP markers to analyze the genetic diversity in Psidium accessions, adopting the strategy of transferability of SNPs developed for Eucalyptus species. The transferability of SNPs of different species is a pioneer and can assist in developing saturated linkage guava maps as well as mapping more accurately multipleagronomical important traits to the crop. The SNP loci identified in this study can be used in studies about guava genetic diversity and can be added to SNPs that may be developed specifically for Psidium species, which will be the best scenario for this species.

\section{CONCLUSION}

The SNP transferability of Eucalyptus to Psidium species was very reliable since amplifications of Eucalyptus SNP sequences in Psidium genome occurred, agreeing with previous microsatellite genetic divergence studies and the SNP dendrogram with the biological Psidium genus structure, since different species were not grouped.

\section{ACKNOWLEDGMENTS}

The authors wish to thank FAPESB for a scholarship for S.R. Costa. These activities were supported by a Universal project of CNPq. C.A.F. Santos is a CNPq researcher.

\section{REFERENCES}

Almeida EJ, Santos JM and Martins ABG (2009). Resistência de goiabeiras e araçazeiros a Meloidogyne mayaguensis. Pesqui. Agropecu. Bras. 44: 421-423. https://doi.org/10.1590/S0100-204X2009000400014

Arriel NHC, Di Mauro AO, Di Mauro SMZ, Bakke AO, et al. (2006). Técnicas multivariadas na determinação da diversidade genética em gergelim usando marcadores RAPD. Pesq. Agropec. Bras. 801-809.

Briceño A, Aranguren Y and Fermin G (2010). Assessment of guava-derived SSR markers for the molecular characterization of Myrtaceae from different ecosystems in Venezuela. Acta Hortic. 849: 139-146. https://doi.org/10.17660/ ActaHortic.2010.849.15

Castro JMCE, Santos CAF and Flori JE (2012). Reaction of Psidium accessions to the nematode Meloidogyne enterolobii. Acta Hortic. 959: 51-57. https://doi.org/10.17660/ActaHortic.2012.959.5

Corrêa LC, Santos CAF, Lima GPP, Rodrigues MA, et al. (2011). Similaridade genética entre acessos de goiabeiras e araçazeiros baseada em marcadores moleculares AFLP. Rev. Bras. Frutic. 33: 859-867. https://doi.org/10.1590/ $\underline{\mathrm{S} 0100-29452011000300021}$

da Costa SR and Santos CAF (2013). Allelic database and divergence among Psidium accessions by using microsatellite markers. Genet. Mol. Res. 12: 6802-6812. https://doi.org/10.4238/2013.December.16.6

Costa IR, Dornelas MC and Forni-Martins ER (2008). Evolution of nuclear DNA amounts in Neotropical Myrtacea (fleshfruited Myrtacea). Plant Syst. Evol. 276: 209-217.

Costa SR, Santos CAF and Castro JMC (2012). Assessing Psidium guajava x P. guineense hybrids Tolerance to Meloidogyne enterolobii. Acta Hortic. 959: 59-62. https://doi.org/10.17660/ActaHortic.2012.959.6

Doyle JJ and Doyle JL (1990). Isolation of plant DNA from fresh tissue. Focus 12: 13-15.

Hernández-Delgado, Padilla-Ramírez JS, Cedillo AN and Perez NM (2007). Morphological and genetic diversity of Mexican guava germoplasm. Plant Genet. Resour. 5: 131-141. https://doi.org/10.1017/S1479262107827055

Hirano RT (1967). Chromosomal and pollination studies as related to intra-specific and interspecific compatibility in the genus Psidium. Master's thesis, University of Hawaii, Honolulu.

Genetics and Molecular Research 16 (2): gmr16029566 
Kidaha LM, Alakonya AE and Nyende AB (2014). Molecular Characterization of Guava Landraces in Kenya (Western and South Coast). J. Bio. Agr. Healthc 4: 81-86.

Miranda GB, Souza RM and Viana AP (2011). Assessment of methods and criteria for screening Psidium ssp for resistance to Meloidogyne enterolobii. Nematol. Bras. 34: 211-219.

Oliveira NNS, Viana AP, Quintal SSR, Paiva CL, et al. (2014). Análise de distância genética entre acessos do gênero Psidium via marcadores ISSR. Rev. Bras. Frutic. 36: 917-923. https://doi.org/10.1590/0100-2945-413/13

Pessanha PGO, Viana AP, Junior ATA, Souza RM, et al. (2011). Avaliação da diversidade genética em acessos de Psidium ssp. via marcadores RAPD. Rev. Bras. Frutic. 33: 129-136. https://doi.org/10.1590/S0100-29452011000100018

Pommer CV, Oliveira OF and Santos CAF (2013). Goiaba Recursos Genéticos Melhoramento. Editora UFERSA, Mossoró.

Pritchard JK, Stephens M and Donnelly P (2000). Inference of population structure using multilocus genotype data. Genetics 155: 945-959.

Rai MK, Phulwaria M and Shekhawat NS (2013). Transferability of simple sequence repeat (SSR) markers developed in guava (Psidium guajava L.) to four Myrtaceae species. Mol. Biol. Rep. 40: 5067-5071. https://doi.org/10.1007/ s11033-013-2608-1

Ray PK (2002). Guava. In: Breeding Tropical and Subtropical Fruits. Narosa Publishing House, Nova Delhi, 143-154.

Rophlf FJ (2000). NTSYS-pc numerical taxonomy and multivariate analysis system, version 1.80. Exeter Software, Setauket.

Rueda A, Palacio JD, Muñoz JE, Saavedra R, et al. (2006). Caracterización molecular del banco de germoplasma de guayaba Psidium spp. del centro de investigación Corpoica-palmira. Fitol. Colom 6: 26-32.

Silva-Junior OB, Faria DA and Grattapaglia D (2015). A flexible multi-species genome-wide 60K SNP chip developed from pooled resequencing of 240 Eucalyptus tree genomes across 12 species. New Phytol. 206: 1527-1540. https:// doi.org/10.1111/nph.13322

Singh R and Sehgal OP (1980). Studies on the blossom biology of Psidium guajava L. (guava).; 2, Pollen studies stigmatal receptivity pollination and fruit set. Indian J. Hortic. 25: 52-59.

Sitther VD, Zhang DDL, Harris DL, Yadav AK, et al. (2014). Genetic characterization of guava (Psidium guajava L.) germplasm in the United States using microsatellite markers. Genet. Resour. Crop Evol. 61: 829-839. https://doi. org/10.1007/s10722-014-0078-5

Sobral M, Proença C, Souza M, Mazine F and Lucas E (2016). Myrtaceae in Lista de Espécies da Flora do Brasil. Jardim Botânico do Rio de Janeiro. Available at [http://floradobrasil.jbrj.gov.br/jabot/floradobrasil/FB62556]. Accessed January 18, 2016.

Valdés-Infante J, Rodriguéz NN, Becker D, Velázquez BL, et al. (2007). Microsatellite characterization of guava (Psidium guajava L) germplasm collection in Cuba. Cultiv Tropic. 28: 61-67.

Genetics and Molecular Research 16 (2): gmr16029566 